\title{
THE SHAREHOLDER WEALTH EFFECTS OF AN EXECUTIVE JOINING ANOTHER COMPANY'S BOARD
}

\author{
John Byrd* \\ University of Colorado Denver, USA. \\ L. Ann Martin \\ University of Colorado Denver, USA. \\ Subhrendu Rath \\ Curtin University of Technology, Perth, Australia.
}

* Corresponding author 


\section{Introduction}

The senior executives - the CEO, Chairman and President - are the individuals most responsible for a company’s strategic direction as well as its major financial, marketing and operating decisions. Their involvement in these crucial activities contributes to the company's success or failure. Because these tasks require a broad set of talents and enormous energy, senior executives of large companies are highly compensated. Not infrequently, however, high-level corporate officers join the boards of other publicly traded companies. High-level corporate executives make ideal director candidates because of their management experience and awareness of economic conditions. Lorsch and MacIver (1989) report that 69\% of outside directors are active CEOs at other firms. A more recent survey by the management recruiting agency Spencer Stuart (2001) found that in 2000 47\% of outside directors were active CEOs, corporation presidents or COOs. The Spencer Stuart survey also reports that on average a corporate CEO holds 1.2 other corporate directorships. Booth and Deli (1996) found that CEOs of S\&P 500 firms in 1990 held 1.87 other directorships on average. S\&P 500 companies average eight board meetings per year, though for individual firms the number of meetings ranges from 4 to over 20 (Spencer Stuart, 2001). In accepting a board seat, an executive commits an average of 8 to 10 days per year to help oversee the affairs of another company. The time commitment can be much larger depending on required preparation, travel time and the particular board-level events of the company. This commitment reduces the time the executive can devote to the company they manage and that pays their salary. Commentators have begun questioning whether CEOs should join other boards (Dobrzynski, 1996). 
Sitting on another company's board obviously takes time that could be expended on the affairs of the home firm. Presumably a senior executive would explain to the home firm board how these extra duties help create value for home-company shareholders. Various hypotheses have been suggested for the value of an active CEO (or other senior executive) sitting on other boards. Bacon and Brown (1974) argue that serving on the board of another firm may help CEOs become more effective managers within their own firms. Watching other experienced managers, seeing different management styles in action, gathering information about economic trends, and having other executives with whom to confer, are some of the examples of how sitting on a board might make a senior executive more effective and thereby create value for home firm shareholders.

Agency theory suggests that managers may not always act to maximize shareholder wealth (Jensen and Meckling, 1976). If so, the decision to join another board could be pursued so the executive increases the value of his/her personal human capital or prestige (Mace, 1986). In this case the benefits of sitting on another company's board accrue primarily to the executive. If these board duties reduce the executive's efforts on behalf of the shareholders of the home firm, then joining another board would be value decreasing for the shareholders of the company that employs the executive. Booth and Deli (1996) argue that companies with many growth opportunities have the greatest need for the investment decision expertise of the CEO. If the CEO expends effort elsewhere, for example as a member of another company's board, he or she has less time to devote to the concerns of the home firm.

\section{Previous research}


As detailed empirical studies of board of director activities are relatively new, few have examined the effect of an officer joining another company's board. The most relevant study, Rosenstein and Wyatt (1994), provides the pattern for this research. Rosenstein and Wyatt examine the stock price response at the announcement that an officer of a firm is joining the board of another company. Using data from 1981 through 1985 they report an average negative stock price response of $0.11 \%$ for the executive's home firm at the announcement of the appointment. This announcement date abnormal return is not statistically significant (Z-statistic of -0.69) but the average 4-day return just prior to the announcement is significantly negative. In crosssectional tests, they find that the prior performance of the home firm, labeled 'sending firm' in their paper, is positively correlated with the abnormal return from five days prior to through the announcement date. They interpret this result as implying that companies with poorer performance need their executive officers to devote their efforts to home firm activities, not to other companies, whereas better performing firms may not be hurt by their executives joining other boards. They also find that the abnormal return is negative for non-financial corporations but positive for financial companies. This positive stock price response may be due to officers from financial firms being able to generate new business when they join another company’s board.

Booth and Deli (1996) examine factors that determine the number of other boards a CEO joins. They find that CEOs of companies with more growth opportunities (measured as market-to-book ratio and whether the company is regulated) sit on fewer boards than do other CEOs. They also find that the longer a CEO has held his/her position, the more outside directorships the CEO holds. They interpret this as being consistent with the suggestion that after certain tenure in the position a CEO begins to hand decision authority to a successor. However, 
joining additional boards could also represent opportunistic end-game behavior on the part of a CEO (Dechow and Sloan, 1991).

Ferris, Jagannathan and Pritchard (2003) examine whether outside directors holding multiple board seats affects firm performance. They report that market-to-book ratios are higher for firms with directors holding more board seats. They attribute this result to the labor market for directors allocating more seats to better directors. Their study does not address the question of whether executives holding more board seats affect the performance of the executives' home companies. More recent studies on the topic of busy directors have produced mixed results. Perry and Peyer (2005) report that outside directorship by executives can add value to firms by helping to broaden the executives' expertise and perspective. However, Fich and Shivadasani (2006) find that announcements of addition of directorships in outside boards result in negative abnormal returns.

The current study extends the work of Rosenstein and Wyatt (1994) in two ways. We use data from 1986 through 1997. This period saw a tremendous change in the role of the board of directors in corporate governance as well as an increase in outside scrutiny of the board by institutional investors. Thus, the reaction to active senior executives joining other boards may be different than during the earlier, and presumably more benign, period. Second, we examine several variables Rosenstein and Wyatt (1994) did not include that could potentially explain the extent to which accepting an outside board position affects an executive's effectiveness within the home firm. These variables include the number of other board seats the executive holds at the time of the announcement, whether the executive is near retirement, the executive's position in the home firm (president, CEO, or chairman of the board) and the independence of the home company’s board of directors. 


\section{Sample selection and description}

We follow the sample selection process of Rosenstein and Wyatt (1994). We examine the entire weekly 'Who’s News’ announcements in the Wall Street Journal from January 1986 through December 1997. All announcements of director appointments of a high-level corporate officer - president, CEO, vice-chairman of the board or chairman of the board - of a U.S. company are collected. If the home firm of the newly appointed director is a publicly-traded corporation and there are no potentially confounding announcements in the Wall Street Journal Index for the three trading days surrounding the announcement date, the observation is eligible for our sample. To be included in the final sample, the company must have returns data on the CRSP file for 250 days prior to the announcement date and a proxy statement must be available that lists variables for the executive, such as age and other board seats held. Our final sample consists of 104 announcements by 96 different companies. Four firms appear twice in the final sample, and two firms appear three times. The time distribution of observations is shown in Table 1.

Insert Table 1 here

Table 1 also categorizes the sample by executive title. There are almost equal numbers of CEOs, board chairs and company presidents included in the sample. The table shows that many executives hold more than one position. We document that in $34 \%$ of our sample the executive holds the joint roles of CEO and board chairman.

Over a five-year period Rosenstein and Wyatt (1994) developed a sample of 124 observations. Although we include NASDAQ firms, which Rosenstein and Wyatt did not, our final sample is about the same size as theirs, despite being collected over a longer sample period (13 years in our study compared to just 5 years in their study). This difference in sample sizes can 
be attributed in part to our additional screen of limiting the sample to only high-level executives and requiring a proxy statement for each sample firm. The smaller sample might also be explained by fewer director appointments being made in the late-1980s and 1990s than in earlier periods (Spencer Stuart, 2001).

Table 2 presents summary statistics for several characteristics of the sample. The average age of sample executives is about 55 years, which is appropriate given their high rank in their companies. On average these executives sit on 1.4 other corporate boards. This number rises to over 2 when all board seats are considered (corporate and not-for-profit boards). The number of corporate board seats is similar to that found by Spencer Stuart (2001) and Booth and Deli (1996).

Insert Table 2 here

The board of the executive's home company averages 10.4 members. This is slightly smaller than the size of boards in the 1980s cited in Byrd and Hickman (1992) that ranged from 11 to 13 . Over $61 \%$ of board seats are held by independent outside directors. These are directors with no affiliation to the firm other than their board seat. An outside (non-employee) director might not be categorized as independent if they are associated with a business that trades with the company, a law firm that provides legal services to the company, or a bank that lends to the company. Not reported in Table 2 is that $71 \%$ of sample firms have independent boards; that is, more than $50 \%$ of board seats are held by independent outside directors. This proportion is lower than the $82 \%$ found by Byrd and Hickman (1992). The firms range in size from very small (total assets of $\$ 7$ million) to extremely large. Examples of the large companies included in the sample are: Texaco, Xerox, IBM and AT\&T. 


\section{Univariate results}

Table 3 presents the summary statistics for the 2-day abnormal announcement date returns for our sample. Data from the CRSP daily returns file and the value-weighted market index are used to estimate market model parameters for each observation. The estimated market model parameters, alpha and beta, are ordinary least squares (OLS) estimates using the 241 daily returns beginning on day -250 (that is, 250 trading days before the announcement date which is designated as day 0 ) through day -10 . The abnormal return for each firm over the two-day announcement period is the difference between the actual continuously compounded return for the firm over the two-day period, day -1 and day 0 , and the expected return for that day based on the estimated market model parameters and the continuously compounded value-weighted market return over the same two-day interval.

The average abnormal return is $-0.47 \%$ with a t-statistic of -1.90 (p-value $6 \%$ ), and is statistically significant at the $10 \%$ level. For the entire sample, $63 \%$ of the announcement date abnormal returns are negative. A sign test shows that this proportion is different than a $50 \%$ probability of obtaining a negative return at a significance level of $1.1 \%$. These results differ from those presented by Rosenstein and Wyatt (1994) who found a 2-day abnormal return of just $-0.11 \%$ during their sample period of 1981 through 1985 . The larger stock price response reported here might be due to more investor interest in the activities of corporate executives during the late 1980s and 1990s.

Insert Table 3 here

Other univariate tests compared the abnormal returns by job title. We find that the announcement date abnormal return for board chairs is $-0.63 \%$ (significant at the $5 \%$ level). The 35 observations of individuals who hold both the title CEO and chairman was also negative (- 
0.73\%) and statistically significant (p-value of 6.9\%). We find no statistical difference in the abnormal returns between executive positions. That is, there was no significant difference in the abnormal returns for CEOs joining another company’s board versus non-CEOs, and similarly for presidents or board chairs.

Results for two further tests are not presented in the table. Rosenstein and Wyatt (1994) report a positive stock price response for financial firms whose executives join the boards of other companies. For the three financial firms in our sample we find a mean abnormal announcement date return of $1.2 \%$, which is not statistically different from zero. Eliminating financial firms from the sample we find that the average abnormal return is $-.52 \%$ and statistically significant (p-value $=3.8 \%)$.

We also compared the average abnormal return for executives nearing retirement, defined as over 60 years of age, to younger executives. The average abnormal return for the nearretirement group is $0.16 \%$, which is not statistically different from zero, while the mean for the younger group is $-0.72 \%$ (significantly different than zero with a p-value of $2.4 \%$ ). These means are different at the $6 \%$ level of significance (t-statistic of 1.88).

The results presented in Table 3 are consistent with investors seeing the decision by a key executive to join the board of another company as reducing the value of the home firm. Investors appear to value the loss of managerial effort or expertise more highly than any benefits the executive might derive from observing the workings of another corporation. This effect is not documented among executives close to retirement. Investors may expect more senior executives to join other boards as they transition toward retirement. 


\section{Multivariate results}

We use cross-sectional regression models to more closely examine the factors that might affect the response of investors to the announcement that an executive is joining the board of another company. The dependent variable is the two-day announcement date abnormal return for each sample firm. Rosenstein and Wyatt (1994) find that prior performance is a significant explanatory variable in regressions of the six-day announcement date abnormal return. As a measure of prior performance we used the market-adjusted returns (Firm return minus the CRSP equally weighted index return) for the pre-announcement estimation period of day -250 through day -10 relative to the Wall Street Journal announcement date. We also used industry-adjusted returns for the twelve months prior to the announcement month based on the Fama and French industry portfolios. ${ }^{1}$ The results were nearly identical to the market-adjusted results shown in Table 4, so are not presented. Booth and Deli (1996) suggest that CEO succession can free an executive to be on other boards as they transfer authority to their successor. To capture this notion we include a variable for the age of the executive.

One of our concerns in the present study is whether the growing investor interest in corporate governance issues, particularly related to the CEO and board of directors, applies to executives joining the boards of other companies. One aspect of investor concern is that key executives are spreading themselves too thin when they join other boards (Dobrzynski, 1996). We include a variable for the number of corporate boards that the executive sits on at the time of the announcement about joining another board. We include variables for the position the executive holds in the home company. These are indicator variables for CEO, chairman of the

\footnotetext{
${ }^{1}$ For our industry adjustment we used the 48 industry portfolio data available at: http://mba.tuck.dartmouth.edu/pages/faculty/ken.french/Data_Library/det_48_ind_port_old.html
} 
board, vice-chair or president. We also include an indicator variable to designate situations in which a single executive is both CEO and chairman of the board. The coefficient estimates from regressions using these variables are reported in Table 4. The t-statistics are based on consistent standard errors using the methods of Huber (1967) and White (1980).

Insert Table 4 here

The regression results presented in Table 4 are for the entire sample and show that there is a significant positive relationship between the announcement date abnormal return and an executive’s age. Similar results are found using indicator variables for executives over 60 or over 62 years of age. The variable for the number of other corporate boards the executive sits on at the time of the announcement has a significant negative coefficient. This result is consistent with the 'being spread too thin’ criticism leveled at executives who sit on many boards. An alternative measure of board involvement counted the executive's membership on corporate and not-forprofit boards and boards of associations. This variable had no explanatory power, suggesting that the commitment to non-corporate boards is perceived as being less demanding than to corporate boards.

Unlike Rosenstein and Wyatt (1994) we find no significant relationship between prior stock price performance and the announcement date abnormal return. Nor do variables for executive position in the home firm (CEO or Chair), holding both the CEO and Chair positions, board size or board independence have statistically significant coefficient estimates.

Table 5 presents results from an OLS regression model for a sub-sample comprised of just CEOs. These results reinforce those presented in Table 4 for the entire sample. The large negative intercept term (-0.077) shows that investors disapprove of a CEO committing time to the management of another firm as a member of the board of directors. This significant negative 
response is magnified as the CEO holds more board seats. This result is consistent with the hypothesis that investors believe that as CEOs join more boards they become less effective managing their home firms. This negative effect is attenuated the closer the CEO is to retirement age. Investors may expect CEOs to begin acquiring board seats as they transition to retirement.

An analysis using the sub-sample of board chairs had similar but somewhat weaker results. The age variable had a significant coefficient but the number of board seats coefficient did not. These results are not presented.

Standard tests for robustness and examination of residuals did not reveal any highly influential observations. We also looked at longer event windows, but the standard 2-day window produced the regression results with the most explanatory power.

Overall, our results support the hypothesis that shareholder wealth is dissipated when a high-ranking executive commits time to participating on the board of another corporation. The older an executive is at the time he/she joins another board, the less negative the investor response. For CEOs this value loss increases with the number of corporate boards the CEO already sits on, but is attenuated if the CEO is close to retirement. The results for CEOs support the hypothesis that investors interpret a CEO joining the board of another firm as value decreasing.

\section{Conclusions}

Using a sample of 104 announcements of a high-level executive joining the board of another company from 1985 through 1997, we find a negative announcement date stock response of about one-half of one percent for the firm that employees the executive. Our announcement date stock price response is more negative for executives who hold the dual title of CEO and chairman of the 
board. The stock price response we report is larger (more negative) than that found by Rosenstein and Wyatt (1994) during an earlier sample period with 90\% or more significance level. We attribute the difference in our findings to investors being more attuned to corporate governance issues during our sample period. Although our results are limited by data availability up to 1997, these results carry significance given that the dual role of executives being board chairman and CEO for US corporations has somewhat declined over time (Conyon and Read (2006)).

Our regression analysis shows that an executive’s age and the number of corporate boards on which the executive already sits help explain the cross-sectional variation in the announcement date stock returns. Being close to retirement mitigates the negative stock price effect, but sitting on several other corporate boards accentuates it. This last result supports the concerns of shareholder activists that key executives joining the boards of other companies do their home shareholders a disservice by being spread too thin. While there are potential benefits for the home company from the CEO joining another board (Perry and Peyer (2005)), such as networking and learning opportunities, our results suggest that on average these benefits do not offset the value losses from a CEO committing to the high demands of a new board seat.

\section{References}

Booth, J., and D. Deli, 1996, Factors affecting the number of outside directorships held by CEOs, Journal of Financial Economics, 40, 81-104.

Byrd, J., and K. Hickman, 1992, Do outside directors monitor managers? Journal of Financial Economics 32, 195-221.

Conyon M., and L. Read, 2006, A model of the supply of executives for outside directorships, Journal of Corporate Finance, 12: 3, 645-659

Dechow, P. and R. Sloan, 1991, Executive incentives and the horizon problem: An empirical investigation, Journal of Accounting and Economics, 14, 51-89. 
Dobrzynski, J., 1996, When Directors Play Musical Chairs, New York Times, November 17, Section 3, Page 1.

Fama, E., and M. Jensen, 1983. Separation of ownership and control. Journal of Law and Economics 26, 301-326.

Fama, E. and D. French, 48 Industry Portfolio data, available at: http://mba.tuck.dartmouth.edu/pages/faculty/ken.french/Data_Library/det_48_ind _port_old.html

Ferris, S., M. Jagannathan, and A. Pritchard, 2003, Too busy to mind the business? Monitoring by directors with multiple board appointments, Journal of Finance, 53(3), 1087-1111.

Fich, E. and A. Shivdasani, 2006, Are busy boards effective monitors? Journal of Finance 61 (2): 689-724.

Huber, P., 1967, The behavior of maximum likelihood estimates under non-standard conditions. In Proceedings of the Fifth Berkeley Symposium on Mathematical Statistics and Probability, University of California Press, 1, 221-233.

Jensen, M., and W. Meckling, 1976, Theory of the firm: Managerial behavior, agency costs, and ownership structure, Journal of Financial Economics, 3, 305-360.

Lorsch, J., and E. MacIver, 1989, Pawns or Potentates: the reality of America's corporate boards (Harvard Business School Press, Boston, MA).

Mace, M., 1986, Directors: myth and reality (Harvard University, Boston, MA)

Perry, T and U. Peyer, 2005, Board seat accumulation by executives: A shareholder's perspective. Journal of Finance 60 (4): 2083-2123.

Rosenstein, S. and J. Wyatt (1994) Shareholder wealth effects when an officer joins the board of directors of another firm, Managerial and Decision Economics, 15, 31727.

Spencer Stuart, 2001, Spencer Stuart Board Index 2001.

White, H., 1980, A heteroskedaticity-consistent covariance matrix estimator and a direct test for heteroskedasticity, Econometrica, 48, 817-830. 
Table 1

Distribution of announcements over time and by executive title.

\begin{tabular}{|c|c|c|c|c|c|c|c|}
\hline Year & Total & CEOs & Chairman & President & CEO/Chair & $\begin{array}{c}\text { CEO/Chair/ } \\
\text { Pres }\end{array}$ & CEO/Pres \\
\hline 1985 & 1 & 1 & 1 & 0 & 1 & 0 & 0 \\
1986 & 7 & 3 & 4 & 5 & 1 & 0 & 1 \\
1987 & 2 & 1 & 2 & 0 & 1 & 0 & 0 \\
1988 & 7 & 5 & 3 & 3 & 3 & 0 & 1 \\
1989 & 3 & 1 & 2 & 2 & 0 & 0 & 1 \\
1990 & 6 & 5 & 2 & 5 & 2 & 1 & 4 \\
1991 & 14 & 8 & 9 & 6 & 6 & 1 & 3 \\
1992 & 17 & 7 & 9 & 8 & 5 & 1 & 2 \\
1993 & 12 & 6 & 5 & 10 & 2 & 1 & 5 \\
1994 & 11 & 8 & 7 & 5 & 5 & 2 & 4 \\
1995 & 9 & 6 & 6 & 4 & 4 & 0 & 3 \\
1996 & 7 & 6 & 3 & 3 & 2 & 3 & 3 \\
1997 & 8 & 5 & 4 & 5 & 3 & 2 & 30 \\
\hline Total & 104 & 62 & 57 & 56 & 35 & 9 & 3 \\
\hline
\end{tabular}

Table 2

Summary statistics of executive and home firm characteristics for a sample

\begin{tabular}{|r|c|c|c|c|c|c|}
\hline & Age & $\begin{array}{c}\text { Other } \\
\text { Corp } \\
\text { Boards }\end{array}$ & $\begin{array}{c}\text { All Other } \\
\text { boards }\end{array}$ & Board size & $\begin{array}{c}\text { \% Independent } \\
\text { Outside } \\
\text { Directors }\end{array}$ & $\begin{array}{c}\text { Total } \\
\text { Assets } \\
\$ m m\end{array}$ \\
\hline Mean & 54.7 & 1.4 & 2.1 & 10.4 & $61.3 \%$ & 8,483 \\
\hline Median & 55 & 1 & 1 & 10.5 & $67 \%$ & 1,805 \\
\hline Minimum & 35 & 0 & 0 & 5 & $0 \%$ & 7 \\
\hline
\end{tabular}


Table 3

Univariate test results of the announcement date 2-day home company abnormal

\begin{tabular}{|r|c|c|c|c|c|}
\hline & $\begin{array}{c}\text { Entire } \\
\text { sample }\end{array}$ & CEO & Chairman & President & $\begin{array}{c}\text { Chairman } \\
\text { and CEO }\end{array}$ \\
\hline Mean & -0.0047 & -0.0048 & -0.0063 & -0.0022 & -0.0073 \\
Std. Dev. & 0.025 & 0.025 & 0.024 & 0.025 & 0.022 \\
Z-score (Ho:Mean=0) & -1.90 & -1.52 & -2.00 & -0.670 & -1.88 \\
p-value & 0.06 & 0.134 & 0.048 & 0.51 & 0.069 \\
\hline Median & -0.0049 & -0.0049 & -0.004 & -0.005 & -0.0048 \\
Smallest & -0.090 & -0.071 & -0.090 & -0.071 & -0.069 \\
Largest & 0.083 & 0.083 & 0.046 & 0.083 & 0.046 \\
\hline \% negative & $62.5 \%$ & $60 \%$ & $61.4 \%$ & $59 \%$ & $60 \%$ \\
t-statistic (Ho: \% $=50)$ & 2.55 & 1.52 & 1.72 & 1.34 & 1.18 \\
\hline p-value & 0.011 & 0.134 & 0.085 & 0.180 & 0.238 \\
\hline Observations & 104 & 62 & 57 & 56 & 35 \\
\hline
\end{tabular}


Table 4

Linear regression results models with abnormal return of the executive's home company as the dependent variable and various firm and executive characteristics as explanatory variables.

\begin{tabular}{|c|c|c|c|c|c|}
\hline & Model 1 & Model 2 & Model 3 & Model 4 & Model 5 \\
\hline $\begin{array}{l}\text { Intercept } \\
\text { t-statistic } \\
\text { p-value } \\
\end{array}$ & $\begin{array}{c}-0.0605 \\
-2.88 \\
(0.01) \\
\end{array}$ & $\begin{array}{c}-0.0596 \\
-2.88 \\
(0.01) \\
\end{array}$ & $\begin{array}{c}-0.0606 \\
-2.93 \\
(0.00) \\
\end{array}$ & $\begin{array}{l}-0.0650 \\
-3.29 \\
(0.00) \\
\end{array}$ & $\begin{array}{c}-0.0665 \\
-3.46 \\
(0.00) \\
\end{array}$ \\
\hline $\begin{array}{r}\text { 1-year Performance } \\
\text { t-statistic } \\
\text { p-value }\end{array}$ & $\begin{array}{l}-0.0036 \\
-0.57 \\
(0.57) \\
\end{array}$ & $\begin{array}{c}-0.0031 \\
-0.50 \\
(0.62) \\
\end{array}$ & $\begin{array}{c}-0.0026 \\
-0.42 \\
(0.67) \\
\end{array}$ & $\begin{array}{c}-0.0021 \\
-0.34 \\
(0.74) \\
\end{array}$ & \\
\hline $\begin{array}{r}\text { Age of executive } \\
\text { t-statistic } \\
\mathrm{p} \text {-value }\end{array}$ & $\begin{array}{c}0.0012 \\
3.10 \\
(0.00) \\
\end{array}$ & $\begin{array}{c}0.0012 \\
3.13 \\
(0.00) \\
\end{array}$ & $\begin{array}{c}0.0013 \\
3.30 \\
(0.00) \\
\end{array}$ & $\begin{array}{c}0.0012 \\
3.23 \\
(0.00) \\
\end{array}$ & $\begin{array}{c}0.0013 \\
3.42 \\
(0.00) \\
\end{array}$ \\
\hline $\begin{array}{r}\text { \# of Board seats held } \\
\text { t-statistic } \\
\text { p-value }\end{array}$ & $\begin{array}{c}-0.0034 \\
-1.59 \\
(0.12)\end{array}$ & $\begin{array}{c}-0.0037 \\
-1.83 \\
(0.07) \\
\end{array}$ & $\begin{array}{c}-0.0036 \\
-1.77 \\
(0.08) \\
\end{array}$ & $\begin{array}{c}-0.0038 \\
-1.89 \\
(0.06)\end{array}$ & $\begin{array}{c}-0.0037 \\
-1.88 \\
(0.06)\end{array}$ \\
\hline $\begin{array}{r}\text { Home Firm Title: CEO } \\
\text { t-statistic } \\
\text { p-value }\end{array}$ & $\begin{array}{c}0.0012 \\
0.17 \\
(0.86)\end{array}$ & & & & \\
\hline $\begin{array}{r}\text { Home Firm Title: Chair } \\
\text { t-statistic } \\
\text { p-value }\end{array}$ & $\begin{array}{c}-0.0033 \\
-0.43 \\
(0.67)\end{array}$ & & & & \\
\hline $\begin{array}{r}\text { Both Chair \& CEO dummy } \\
\text { t-statistic } \\
\text { p-value }\end{array}$ & $\begin{array}{c}-0.0042 \\
-0.45 \\
(0.66)\end{array}$ & $\begin{array}{c}-0.0056 \\
-1.09 \\
(0.28)\end{array}$ & $\begin{array}{l}-0.0056 \\
-1.08 \\
(0.28) \\
\end{array}$ & $\begin{array}{c}-0.0054 \\
-1.05 \\
(0.30)\end{array}$ & $\begin{array}{c}-0.0054 \\
-1.07 \\
(0.29)\end{array}$ \\
\hline $\begin{array}{r}\text { Size of board } \\
\text { t-statistic } \\
\text { p-value }\end{array}$ & $\begin{array}{l}-0.0008 \\
-0.86 \\
(0.39)\end{array}$ & $\begin{array}{l}-0.0008 \\
-0.92 \\
(0.36)\end{array}$ & $\begin{array}{c}-0.0007 \\
-0.75 \\
(0.46)\end{array}$ & & \\
\hline $\begin{array}{r}\text { Independent Board dummy } \\
\text { t-statistic } \\
\text { p-value }\end{array}$ & $\begin{array}{c}0.0055 \\
1.00 \\
(0.32)\end{array}$ & $\begin{array}{c}0.0054 \\
0.99 \\
(0.33)\end{array}$ & & & \\
\hline $\begin{array}{r}\text { Number of observations } \\
\text { F-statistic } \\
\text { P-value of F } \\
\text { R-squared }\end{array}$ & $\begin{array}{c}104 \\
1.79 \\
(0.09) \\
13.1 \%\end{array}$ & $\begin{array}{c}104 \\
2.36 \\
(0.04) \\
12.8 \%\end{array}$ & $\begin{array}{c}104 \\
2.64 \\
(0.03) \\
11.9 \%\end{array}$ & $\begin{array}{c}104 \\
3.18 \\
(0.02) \\
11.4 \%\end{array}$ & $\begin{array}{c}104 \\
4.23 \\
(0.01) \\
11.3 \%\end{array}$ \\
\hline
\end{tabular}




\section{Table 5}

Linear regression with the announcement date abnormal return of the CEO's home company as the dependent variable and various firm and executive characteristics as explanatory variables.

\begin{tabular}{|c|c|c|c|c|}
\hline & Model 1 & Model 2 & Model 3 & Model 4 \\
\hline Intercept & $\begin{array}{l}-0.0772 \\
-2.83 \\
(0.01)\end{array}$ & $\begin{array}{l}-0.0770 \\
-2.95 \\
(0.01)\end{array}$ & $\begin{array}{c}-0.0779 \\
-3.14 \\
(0.00)\end{array}$ & $\begin{array}{c}-0.0771 \\
-3.10 \\
(0.00)\end{array}$ \\
\hline $\begin{array}{r}\text { 1-year Performance } \\
\text { t-statistic } \\
\text { p-value }\end{array}$ & $\begin{array}{l}-0.0009 \\
-0.12 \\
(0.91)\end{array}$ & $\begin{array}{l}-0.0009 \\
-0.12 \\
(0.91)\end{array}$ & & \\
\hline $\begin{array}{r}\text { Age of executive } \\
\text { t-statistic } \\
p \text {-value }\end{array}$ & $\begin{array}{l}0.0014 \\
2.77 \\
(0.01) \\
\end{array}$ & $\begin{array}{c}0.0014 \\
2.81 \\
(0.01)\end{array}$ & $\begin{array}{c}0.0014 \\
3.01 \\
(0.00) \\
\end{array}$ & $\begin{array}{c}0.0014 \\
2.88 \\
(0.01) \\
\end{array}$ \\
\hline $\begin{array}{r}\text { \# of Board seats held } \\
\text { t-statistic } \\
\text { p-value }\end{array}$ & $\begin{array}{l}-0.0052 \\
-1.99 \\
(0.05)\end{array}$ & $\begin{array}{l}-0.0052 \\
-2.05 \\
(0.05)\end{array}$ & $\begin{array}{l}-0.0052 \\
-2.08 \\
(0.04)\end{array}$ & $\begin{array}{l}-0.0058 \\
-2.32 \\
(0.02)\end{array}$ \\
\hline $\begin{array}{r}\text { Both Chair \& CEO dummy } \\
\text { t-statistic } \\
\text { p-value }\end{array}$ & $\begin{array}{l}-0.0075 \\
-1.20 \\
(0.24)\end{array}$ & $\begin{array}{c}-0.0075 \\
-1.21 \\
(0.23)\end{array}$ & $\begin{array}{l}-0.0075 \\
-1.22 \\
(0.23)\end{array}$ & \\
\hline $\begin{array}{l}\text { Size of board } \\
\text { t-statistic } \\
\text { p-value }\end{array}$ & $\begin{array}{l}0.00003 \\
0.03 \\
(0.98)\end{array}$ & & & \\
\hline $\begin{array}{r}\text { Independent Board dummy } \\
\text { t-statistic } \\
\text { p-value }\end{array}$ & $\begin{array}{c}0.0092 \\
1.35 \\
(0.18)\end{array}$ & $\begin{array}{c}0.0092 \\
1.41 \\
(0.16)\end{array}$ & $\begin{array}{l}0.0092 \\
1.42 \\
(0.16)\end{array}$ & $\begin{array}{l}0.0086 \\
1.32 \\
(0.19)\end{array}$ \\
\hline $\begin{array}{r}\text { Number of obs } \\
\text { F-statistic } \\
\text { p-value } \\
\text { R-squared }\end{array}$ & $\begin{array}{c}62 \\
2.27 \\
(0.05) \\
19.8 \% \\
\end{array}$ & $\begin{array}{c}62 \\
2.77 \\
(0.03) \\
19.8 \%\end{array}$ & $\begin{array}{c}62 \\
3.52 \\
(0.01) \\
19.8 \% \\
\end{array}$ & $\begin{array}{c}62 \\
4.17 \\
(0.01) \\
17.7 \% \\
\end{array}$ \\
\hline
\end{tabular}

